\title{
THE STRUGGLE OF LOVE AS REFLECTED IN NICHOLAS SPARK'S THE NOTEBOOK
}

\author{
HARISA MANDASARI ${ }^{1}$ \\ FEBY MEUTHIA YUSUF ${ }^{2}$ \\ RAFLIS $^{3}$
}

\author{
Volume 1 Nomor 1 \\ JILP \\ ISSN: 2581-0804 \\ E-ISSN: 2581-1819
}

\begin{abstract}
The notebook is a romantic novel by literary writer Nicholas Sparks. The analysis focuses on the story line narrated by Noah Calhoun. Noah is a young man from a poor family, Noah is in love with Allie a girl from a wealthy family.

This research uses a structural approach. This approach is a pure approach to literature mixing other disciplines into the discussion. The theory used is the extrinsic theory of literature itself, and is also supported by the flow theory where the character Noah Calhoun seeking his true love. This study also uses structural methods, in which all data is only analyzed in the elements that make up the literary works themselves, such as grooves and characterizations.

In this study the authors found: (1) Noah left Allie because Allie's parents did not approve

of their love story, and Noah decided to go to war. Allie's parents did not approve of their relationship because noah was born from a poor family. And Allie's parents set her up with another man. (2) Noah's love affair occurs when Noah reunites with Allie and new problems arise when Allie is already fiancee with another man. Problems can be seen when the relationship is contrary to the parent because of the difference in status. But Allie kept making sense to Noah about her parents' decisions. (3) when Noah returns with Allie after Allie realizes that she loves Noah over Lon and after Allie's parents see her daughter's love for Noah they finally agree on the relationship. This novel tells about the love of the first story that turned into true love. And this novel tells about how a character Noah to be able to maintain his first love despite many obstacles.
\end{abstract}

Keywords: structural pendentance, the application of extrinsic theory, supported by storyline, analyzed in the form of literary works, and supported by characters.

\section{ABSTRAK}

The notebook merupakan novel romantis karya penulis sastra Nicholas Sparks. Analisis di fokuskan pada alur cerita yang dinarasikan oleh Noah Calhoun. Noah merupakan seorang pemuda yang berasal dari keluarga miskin, Noah jatuh cinta kepada Allie seorang gadis yang berasal dari keluarga kaya.

Penelitian ini mempergunakan

pendekatan struktural. Pendekatan ini merupakan pendekatan murni terhadap sastra mencampurkan disiplin ilmu lain ke dalam pembahasan. Teori yang digunakan adalah teori ekstrinsik sastra itu sendiri, dan juga didukung oleh teori alur dimana tokoh Noah Calhoun mencari cinta sejatinya. Penelitian ini juga mempergunakan metode struktural, di mana 
seluruh data hanya dianalisis dalam unsur yang membentuk karya sastra itu sendiri, seperti alur dan penokohan.

Dalam penelitian ini penulis menemukan : (1)Noah meninggalkan Allie karena orang tua Allie tidak menyetujui kisah cinta mereka, dan Noah memutuskan untuk pergi perang. Orang tua Allie tidak menyetujui hubungan mereka karena noah terlahir dari keluarga miskin. Dan orang tua Allie menjodohkannya dengan pria lain. (2) masalah cinta Noah terjadi ketika Noah reuni bersama Allie dan masalah baru muncul ketika Allie sudah tunangan bersama pria lain. Masalah dapat dilihat ketika hubungannya bertentangan dengan orang tua karena perbedaan status. Tapi Allie tetap membuat pengertian kepada Noah tentang keputusan orang tuanya. (3) ketika Noah kembali dengan Allie setelah Allie menyadari bahwa dia mencintai Noah lebih dari Lon dan setelah orang tua Allie melihat cinta putrinya kepada Noah akhirnya mereka menyetujui hubungan itu. Novel ini menceritak tentang cinta kisah pertama yang berubah menjadi cinta sejati. Dan novel ini menyampaikan tentang bagaimana seorang karakter Noah untuk dapat mempertahankan cinta pertamanya meskipun banyak rintangan.

\section{Kata kunci: kosenp pendektan struktural, penerapan teori ekstrinsik,di dukung alur cerita, dianalisis dalam bentuk karya sastra, dan di dukung oleh tokoh.}

\section{INTRODUCTION}

Literature is something that refers or relates to literary property (the set of knowledge relating to the write and read well, or the art of poetry, rhetoric and grammar). So a literary work is the creation of communicative intent conveyed by the author for aesthetic purposes. These works often tell a story, either in the first or third person, with the plot and through the use of various literary devices associated with their time.

According to the form or subject, literary works may have different types such as narrative (a prose works, such as novels or short stories), poetry (composition in verse that expresses the feelings of the author), drama, epic (the verses that tell the action hero or god) or teaching (which seeks to direct the reader or listener). as a great overview of the analysis, particularly about the reasons for choosing the analysis itself, in this case the analysis is a novel of Nicholas Sparks the notebook. Therefore, the author began this paper with the understanding of literature, facts, issues, and solutions.

\section{METHOD}

structural method. According to Pradopo (2001: 69) The researcher has role to explain literary

\section{CONCLUSIONS}

Allie's conflict is her own anger upon herself to make a right decision on her choice. She fails to control her emotional anger because of her inability convince her parents about her rights. She has been trapped on family tradition concept that the rich must marry the rich or at least in the same level of social status. Therefore, the personal confusion about the rightness which one is truly right is very personal to be answered.

1. The first phase is when Noah meets with Allie in the beginning but suddenly ended because work as a structure based on the elements that build them.
Allie's parents do not approve of their relationship.

Noah leave his past by going to Atlanta and work there he join the army for world war II. He go with one of this bestfriend, fin. He ask Noah to join the war. He go for a while to stay away from Allie because of Allie's parents ignore their relationship. Finally he moved on from Allie because of his busyness for the war. 
2. The second phase is when Noah fix his problem by sending a letter for Allie. He send her some letter to tell her that b can't be apart with her and always thinking about her. Sadly, Allie's parent never give her the letter, they hide it from her. The purpose of his letter is to tell Allie the truth why h love to go and join the world war II. And also Allie have told Fin to send her letter like what Noah's do.

Noah meets with Alli again after World War but also suddenly ended because Allie has

been engaged with another man,Lon.

3. The third phase is when Noah and Allie finally meet each other after being seporoted for 7 years. Allie saw Noah's picture in on of the newspaper which has house selling advertising. Noah finally choose Allie as his life partner and Allie accept it. At the end, Allie live with Noah in their dream house.

\section{SUGGESTIONS}

As a kind of literature, novel is a social medium to understand what life is. It is a summary of life matters that has been imagined and created by the novelist. Nicholas Sparks' The Notebook is a good example to be one that tells life problem experienced by characters or people in common. Because of that this novel is good enough to tell how people must face the life when problems or conflicts happen. It describes what has happened in the past to be known at present so the readers may anticipate the future. So, the writer of this thesis suggested that it is good to be analysed accademically or personally.

The analysis of this thesis is only a part from many possibilities that can be studied scientifically. This thesis can be applied as reference for further study for those who want to deal with this novel or novels in general. With great confidence, the writer of this thesis wants to say that literature is a summary of life that needs learning wisely and seriously. This idea is admittedly represented in the novel The Notebook

The writer also realizes her limited knowledge and material in finishing this thesis. The writer would be glad to invite the readers to give correction, suggestion, or any other input for the weakness of this writing.

\section{BIOGRAPHY OF NICHOLAS SPARKS}

Nicholas Sparks was born in 1965 in Omaha, Nebraska, the second of three children. His father, Patrick Michael (Mike), was a graduate student for much of Nicholas' early life, so the family lived in a number of college towns before settling in Fair Oaks, California, when Nicholas was eight. Nicholas' mother, Jill EmmaMarie (Jill), worked as both a homemaker and optometrist's assistant. All three Sparks children, including Nicholas' older brother, Micah, and younger sister, Danielle, were born within a three-year period, and the closeness in age created a strong bond between them.

Nicholas excelled in high school, graduating valedictorian of his class and earning notice as a middle-distance runner. He accepted a full athletic scholarship to the University of Notre Dame and set a school record as part of a relay team, but he found himself hampered by an Achilles tendon injury the summer after his freshman year. With time on his hands and little to do but recover, Nicholas wrote his first novel, The Passing, which was never published. According to Nicholas, it will never be, but the experience began to hone his writing skills.

Nicholas graduated from Notre Dame in 1988 with a degree in finance and married his wife, Cathy, in 1989, a year that would also bring a deep sadness to Nicholas' life - his mother passed away at the age of 47 from a horseback riding accident. That year was also when Nicholas wrote his second novel, The Royal Murders, which also remains unpublished. Over the next three years, Nicholas experimented with jobs in a number of industries, including real estate appraisal, home restoration, food service, and dental supply sales. With little training in medical sales, Nicholas then started an orthopedic products manufacturing company that brought in little income. He experienced two bright spots during that time, though, including the birth of his son Miles and the chance to coauthor a book with Olympic gold medalist Billy Mills, entitled Wokini, a title that went on to sell over 50,000 copies.In 1992, Nicholas experienced more change, more joy, and more tragedy. He sold 
his company, took a job in pharmaceutical sales, and moved to North Carolina; he and Cathy also learned that Cathy was pregnant with their second child (Ryan, born 1993). That same year, however, Nicholas also learned that his sister had developed cancer, an illness that would later claim her life.

At the age of 28, Nicholas decided to make another concerted, even more serious, effort at writing. To that end, he spent the second half of 1994 writing a novel he called The Notebook, scheduling his writing time around his family's schedule. A year later, while living in Greenville, South Carolina, where he was transferred for his pharmaceutical sales job, Nicholas was offered a contract by a young, new agent with no published novels to her credit. Despite her inexperience, however, Theresa Park was able not only to sell the manuscript to Warner Books but also to secure a $\$ 1$ million advance, much to the Nicholas' shock . . . and elation! Ms. Park, along with United Talent Agency, also sold the film rights to New Line Cinema

\section{SYNOPSIS OF THE NOTEBOOK}

The Notebook is a love story about a man named Noah Calhoun, a veteran from World War II, and his relationship with a woman called Allie Nelson. The story starts off with Noah reading to a woman in his nursing home. He tells her about his love life after his return from the war. The story goes like this:

Noah fell in love with a woman named Allie, but hadn't seen her in 14 years. He decides to rebuild his house, and Allie comes over to visit him at New Bern after reading about it in the newspaper. During the years in which they were apart, Noah had written many letters to Allie, but Allie hadn't responded to any of them, so Noah had assumed that their friendship was over. Allie finds out about Noah's letters, although she had received none of them. Allie decides that her mother must have hidden them away from her, hoping to break off their relationship because of social class differences; Noah was from the working class while Allie was from a wealthy family. She informs Noah that she now has a fiance, called Lon Hammond, whom she is engaged to. Allie's mother shows up at his house and hands over Noah's letters to Allie. Allie is caught in a hard decision and can either choose to stay with Noah, who was her first true love, or with Lon, whom she does not want to hurt. Allie returns to the hotel, where Lon is waiting for her, and tells him that she had made her decision to stay with Noah.

Here, Noah stops reading to the woman, who is actually his wife, Allie. Now, Allie has been diagnosed with Alzheimer's disease, and cannot remember who she is, or who Noah is. Noah also has to deal with his own health problems. As Noah continues reading the story to Allie, he tells us about Allie's successful career as an artist. Later on, Allie says she thinks Noah and Allie in the story chose to be with each other. She suddenly remembers Noah and they talk for four hours before she slides back into her hallucination mode. Noah experiences a stroke just a few days later and is taken to the hospital. After he is released, he goes to visit Allie on the day of their 49th anniversary, reading the letter Allie had written to him the day she had been diagnosed with Alzheimer's. She wakes up from her sleep and recognizes him again. Together, they embrace each other for one last time before dying in each other's arms. 


\section{Bibliography}

Abrams. 1993. The Mirror and The Lamp: Romantic Theory and The Critical Tradition.London: Oxford University Press.

Herujiyanto, Antonius. 2001 . Theory of Katresnanism, Yogyakarta: Sanata Dharma University.

Hauck, Paul A..1983.How to love and be loved. London: University Sheldon.
Luxemburg, Jan Van, et.al. 1996.Pengantar Ilmu Sastra. Jakarta: PT. Gramedia.

Pradopo, Rachmat Djoko, et.al. 2001.Metodologi Penelitian Sastra. Yogyakarta: PT. Hanindita Graha Widia.

Searle, Leroy. 2005.New Criticism. Baltimore: The Johns Hopkins University.

Sparks, Nicholas, 1996.The notebook. New York: Warner Books, Inc. 